\section{Properties of DNA Polymerases} from a Radiation-sensitive Mutant of Bacillus subtilis

\author{
Hiroshi Terano, Yasutaro Fujita, ${ }^{*}$ \\ Shingo Hirolshi and Hajime Kadota \\ Laboratory of Microbiology, Department of \\ Fisheries, *Laboratory of Biochemistry, \\ Department of Agricultural Chemistry, \\ Faculty of Agriculture, Kyoto University, \\ Kyoto, Japan
}

Received December 17, 1973

Our previous works have demonstrated that the mutant of Bacillus subtilis which has the reduced DNA polymerase activity (extracts of the mutant have $15 \sim 20 \%$ of the wild type activity with calf thymus DNA used as template), is approximately two to three times as sensitive to $\gamma$-rays as the wild type strain. ${ }^{1)}$ The capacity for rejoining the radiationinduced strand-breaks of DNA in the $B$. subtilis mutant is much lower than that in the wild type strain. ${ }^{2}$ Furthermore, it has been reported by some workers that $B$. subtilis, like Escherichia coli, contains three different DNA polymerases. $^{3 \sim 6)}$ The major activity, DNA polymerase I seems to be essential for the repair of radiation-damaged regions in the DNA, whereas polymerase III does not. The role of polymerase II is still not clear.

In this paper, we report the characterization of a mutant of $B$. subtilis, which has the reduced DNA polymerase activity and is sensitive to $\gamma$-rays.

B. subtilis (Marburg 168, thy ${ }^{-} \operatorname{trp}^{-}$) $(168 \mathrm{Tt})^{7}$ was used as parent or wild type strain. Strain D22 (thy ${ }^{-}$trp $^{-}$), the mutant of $B$. subtilis $168 \mathrm{Tt}$ having the reduced DNA polymerase activity, was kindly supplied by N. Munakata. Cells were grown in the liquid Schaeffer medium $^{8}$ and harvested at the late logarithmic growing stage.

Partial purification of DNA polymerases was carried out following the procedure described by Ganesan, Yehle and $\mathrm{Yu}^{5)}$ with slight modi-

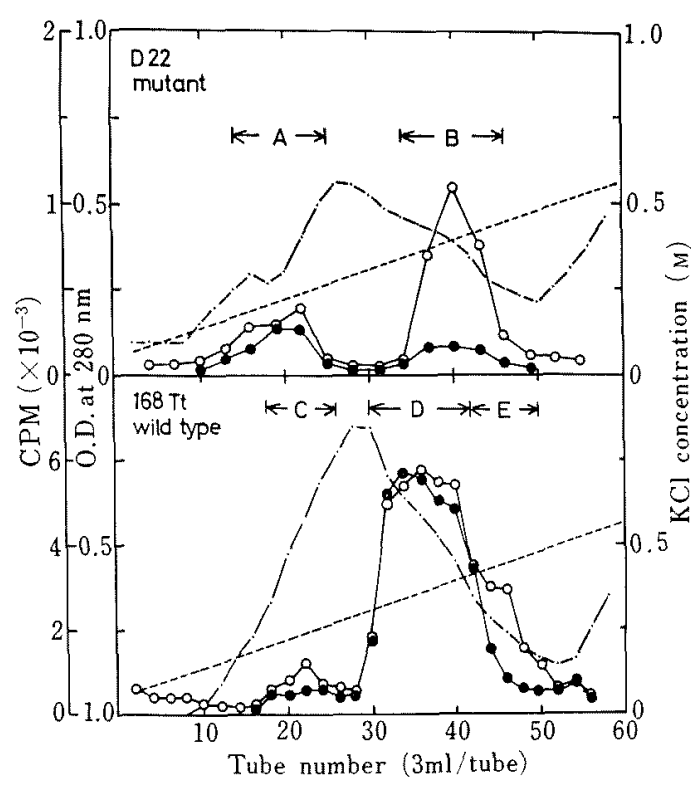

FIG. 1. DEAE-cellulose Chromatography of DNA Polymerases from Mutant (D22) and Wild Type (168Tt) Strains of $B$. subtilis.

The activity of DNA polymerase was assayed in $0.5 \mathrm{ml}$ of an incubation mixture containing $65 \mathrm{~mm}$ Tris- $\mathrm{HCl}$ (pH 8.0), $6.5 \mathrm{~mm} \mathrm{MgCl}, 25 \mu \mathrm{M}$ dATP, dCTP and dGTP, $5 \mu \mathrm{M}$ TTP, $0.5 \mu \mathrm{Ci}{ }^{3} \mathrm{H}$-TTP (specific activity, $15 \mathrm{Ci} / \mathrm{mmole}), 25 \mu \mathrm{g}$ of activated calf thymus DNA and enzyme fraction. The reaction was terminated after $30 \mathrm{~min}$ incubation at $37^{\circ} \mathrm{C}$ by adding carrier yeast RNA and $5 \%$ trichloroacetic acid. The precipitates were collected on Whatman $\mathrm{GF} / \mathrm{C}$ glass fiber filters. The filters were dried and the radioactivity was counted.

$(--)$, absorbance at $280 \mathrm{~nm} ;(0-0)$, DNA polymerase activity; (-), DNA polymerase activity in the presence of 5 mM NEM ; (-..-.-.), KCl concentration.

fications. As shown in Fig. 1, DNA polymerase in strain D22 was separated into two distinct fractions (Fractions $\mathrm{A}$ and $\mathrm{B}$ ) on a DEAE cellulose column. Fractions $A$ and $\mathrm{B}$ were eluted at $0.20 \sim 0.26 \mathrm{M} \mathrm{KCl}$ and $0.35 \sim$ $0.45 \mathrm{M} \mathrm{KCl}$, respectively. On the other hand, the chromatogram of DNA polymerase in strain $168 \mathrm{Tt}$ on DEAE cellulose column revealed one major peak, $\mathrm{D}$, one minor peak, $\mathrm{C}$, and a definite shoulder, $\mathrm{E}$, of polymerase activities. The fractions $\mathrm{C}, \mathrm{D}$ and $\mathrm{E}$ were eluted at $0.21 \sim 0.26 \mathrm{M} \mathrm{KCl}, 0.30 \sim 0.40 \mathrm{M} \mathrm{KCl}$ and $0.40 \sim 0.45 \mathrm{M} \mathrm{KCl}$, respectively.

The various fractions and pooled polymerase peaks were assayed to examine further pro- 


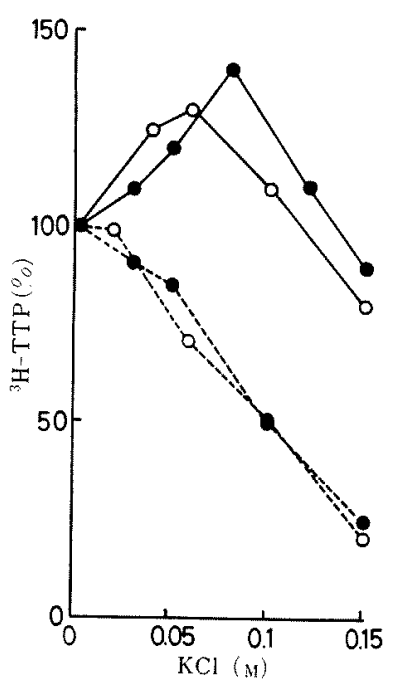

FIG. 2. Effect of $\mathrm{KCl}$ on DNA Polymerase Activity of Various Enzyme Fractions.

$(\bullet-\bullet)$, fraction $A$; (๑--๑), fraction $\mathrm{B}$; $(\mathrm{O}-\mathrm{O})$, fraction $C ;(\mathrm{O}-\mathrm{O})$, fraction $\mathrm{E}$.

perties of DNA polymerases (Figs. 1 and 2, and unpublished data). In strain D22 fraction $A$ was sensitive to $p$-hydroxymercuribenzoate (pHMB) and maximally active at about $0.08 \mathrm{M}$ $\mathrm{KCl}$. Fraction $\mathrm{B}$ was sensitive to $\mathrm{N}$-ethylmaleimide (NEM) and $\mathrm{pHMB}$, and inhibited at all concentrations of $\mathrm{KCl}$ tested. In strain $168 \mathrm{Tt}$ fraction $\mathrm{C}$ was sensitive to $\mathrm{pHMB}$ and maximally active at about $0.06 \mathrm{M} \mathrm{KCl}$. Fraction $\mathrm{E}$ was inhibited by NEM and $\mathrm{pHMB}$ and at all concentrations of $\mathrm{KCl}$ tested. Fraction $D$, however, was not inhibited by NEM and pHMB.

Based on the above-mentioned results and some other reports ${ }^{3 \sim \text { b) }}$ on the properties of DNA polymerases, the following conclusion may be given. The wild type strain $168 \mathrm{Tt}$ possesses at least three different DNA polymerases. Of these, fractions $C, D$ and $E$ seem to correspond to DNA polymerases II, I and III,") respectively. Fractions $\mathrm{A}$ and $\mathrm{B}$ in the mutant strain D22 probably correspond to DNA polymerases II and III, ${ }^{5,6)}$ respectively. These facts suggest that the difference between the mutant and the wild type strains in regard to response to ionizing radiations can be explained at least partly by the genetic differences in the repairing ability, particularly in the DNA polymerase levels of those strains, considering that DNA polymerase I functions primarily in the repair of radiation-damaged DNA.

Studies on the possible role(s) of DNA polymerases and nucleases in the repair system are now in progress.

We wish to thank Dr. T. Komano for helpful advice and discussions.

\section{REFERENCES}

1) H. Terano and H. Kadota, Bull. Inst. Chem. Res., Kyoto Univ., 51, 59 (1973).

2) H. Terano and H. Kađota, Shokuhin Shōsha, 18, 58 (1973).

3) M. M. Neville and N. C. Brown, Nature New Biology, 240, 80 (1972).

4) G. W. Bazill and J. D. Gross, ibid., 240, 82 (1972).

5) A. T. Ganesan, C. O. Yehle and C.C. Yu, Biochem. Biophys. Res. Comm., 50, 155 (1973).

6) N. R. Cozzarelli and R. L. Low, ibid., 51, 151 (1973).

7) J. L. Farmer and F. Rothman, J. Bacteriol., 89, 262 (1965).

8) I. Takahashi, ibid., 89, 294 (1965). 